\title{
Grand challenges in educational psychology
}

\section{Jason W. Osborne* and Melinda J. Mollette}

North Carolina State University, Raleigh, NC, USA

${ }^{*}$ Correspondence: jason_osborne@ncsu.edu

Educational Psychology has a long tradition as a specialty within the field of psychology, formally recognized as a discipline in 1910, when the Journal of Educational Psychology (JEP) began publication. Early psychologists, such as William James and Wilhelm Wundt (e.g., Wundt, 1874; James, 1900) both focused on issues central to educational psychology today (e.g., cognitive processes, memory, and effective teaching).

Indeed, our progress within our discipline has the potential to improve the life of almost every individual, in almost every country, throughout the lifespan. Aside from the classroom, educational psychology can have an impact from the workplace to the military proving ground and the athletic arenas, in home and family life, and beyond. Indeed, some believe that literacy and education can improve both the length and quality of life (e.g., Cleland, 1990). In Latin America, for example, average life expectancy increased from 40 to 70 years at the same time literacy rates increased from 30 to $85 \%$ among adults (Thorp, 1998, p. 2). Similarly impressive changes in other countries have been summarized by numerous scholars (e.g., Crafts, 2000, p. 9). By many measures, the efforts of our field have improved the lives of much of the world's population.

Yet after all these years of scholarship and scientific study, significant challenges remain. We live in an era of unprecedented promise and unprecedented disparity. The gap between the wealthy and poor has increased to obscene proportions around the world. Access to high-quality education remains difficult for too many, even in the wealthiest countries. Some children carry laptops to school and live in constant connection with the resources of the internet, while in some areas students risk physical danger just to go to school. Further, while literacy rates have improved around the world, many students within the US and elsewhere choose not to complete their secondary school education, a decision that has a profound impact on the trajectory of these students' lives. Sadly, many of these students report dropping out of secondary school due to factors such as boredom (Archambault et al., 2009) rather than an inability to succeed in school.

Violence, bullying, and sexual harassment are issues we need to address in the 21 st century. In some areas we are also seeing a disturbing trend toward exclusion (or segregation) of girls from formal education. In many countries we rely upon high-stakes tests to make important decisions about students, while at the same time arguing that it is the " 21 st century skills" of creativity, problem-solving, and information literacy that we care most about. Thus, while employers report a lack of work ethic, writing ability, and critical-thinking skills in recent graduates (Borja, 2006) the educational system continues to prioritize assessment of basic cognitive abilities rather than these " 21 st century skills." Educational psychologists can, and should, have something to say about these issues.

Would the earliest educational psychologists imagine that over 80 years after the unprecedented Winnetka experiment (Corcoran, 1927) that mastery learning (and other scientifically supported educational practices) is scarce in modern classrooms? What would they make of our dropout rates, and the racial/ethnic disparities therein (Greene and Winters, 2002)? And what would they make of our spending priorities in light of the crowded classes we often see and the embarrassingly poor compensation teachers receive for their crucial work? What would they make of the fact that up to half of the eager young teachers in the USA leave the profession within 5 years (Ingersoll and Kralik, 2004)?

As we move into the 21st century, we as educational psychologists and scientists have emerging tools to measure and explore human biology, development, cognition, emotion, behavior, memory, and learning in ways previous generations could only dream of. We have statistical tools to allow us to model processes and systems in highly sophisticated ways through the impressive computing power available in even the most inexpensive computers today. Yet we also work in a world where intellectual relativism seems increasingly common - where "opinion and hypothesis" reign, as the original editors of the JEP noted 100 years ago. Policymakers and practitioners seem increasingly disdainful of scientific findings at the same time that we live in a world of unimaginable scientific breakthroughs. What would James and Wundt and Aristotle and Plato think of school boards in the USA removing discussion of the "theory" of evolution from the curriculum while scientists are decoding our DNA and creating self-replicating synthetic life (Henderson, 2010)? What would they think of girls in certain countries being denied education while at the same time women scientists are leading groundbreaking research throughout the sciences?

Many of us are impatient for the field to utilize best practices in research methods. For example, Robert Slavin, argued that at the "dawn of the $21^{\text {st }}$ century, educational research is finally entering the $20^{\text {th }}$ century." (Slavin, 2002, p. 15). We in the social sciences are guilty of often failing to utilize the most rigorous scientific tools available. In a recent 2 -year period, the JEP contained only $14.6 \%$ true experimental designs, down from $60.0 \%$ in 1969 (Osborne, 2008). Furthermore, almost onequarter of the studies published in this same 2 -year period used college undergraduates as the sole study participants. Would our forebears recognize research published in top Educational Psychology journals today as the type that they envisioned a century ago - research that speaks to educators yearning to identify best practices? And where is the funding for this challenging, yet important research? Within the US there is renewed effort to fund high quality educational research, but this comes after decades of neglect and reductions in funding.

Our challenge, a century from the founding of our discipline, is to be vigorously relevant, using the best tools and methods available. As the editors of JEP noted a 
century ago, we need to engage policymakers and practitioners and to show them the value of funding rigorous research in our discipline. Our challenge today, as it was 100 years ago, is to identify best practices in education and equip current and future teachers with this knowledge to create rigorous, productive, engaging classroom environments. In the original JEP editorial, the editors identified that time as being "ripe for the study of schoolroom problems in the schoolroom itself by the use of the experimental method." This remains true today.

It can be our legacy to make the 21st century the moment when we shrug off the shackles of outdated practices, eschew new ideas that are unproven or ineffective, focus on practices that provide the best cost/benefit ratio, and promote demonstrably best practices in whatever aspect of educational psychology we find ourselves working in. As our understanding of the human brain, biology, chemistry, and social psychology increase, we can leverage this new knowledge in ways previous generations of researchers could never have imagined. With the potential of the internet to communicate research worldwide (especially through open-access scientific publishing!) we, as educational psychologists have unprecedented ability to fulfill the original vision of the field as laid out in that original editorial a century ago - to reach out to practitioners, policymakers, and other researchers to disseminate important findings. We can collaborate easily with individuals in other locations, and work toward a body of knowledge that helps educators identify what works best for whom, and under what conditions.

One example of this sort of work is impressive body of research by Finn and colleagues (e.g., Finn and Achilles, 1999; Finn et al., 2003) that has shown the efficacy of class size reduction in the primary grades on a host of important student outcomes, particularly for those students from traditionally disadvantaged groups (e.g., in the US, students of color; Achilles et al., 1998).

Instructional technology has been the coming panacea since the time of B. F. Skinner (e.g., Skinner, 1960, 1961), and also seems to have the potential for erasing educational disparities. For example, a meta-analysis of 10 years of writing research shows some positive effects on collaboration, effort, and quality in student writing (Goldberg et al., 2003), but other studies find negative effects of instructional technology (e.g., Papanastasiou et al., 2003). Still other research suggests that the most beneficial technologies for student achievement appear least likely to be used in the classroom (Lei and Zhao, 2007).

Still other scholars have shown that returning to basics such as active learning and guided inquiry can make a powerful difference in academic outcomes, again particularly for students at risk (Blanchard et al., 2010). The adoption of manipulatives in early grades mathematics classrooms is a testament to the power of educational psychology to change the landscape of the classroom (e.g., Moyer, 2001).

The list of victories is long, and our space is short. While there have been many victories in the last century, substantial challenges remain. Our hope for this journal is that scholars will use this openaccess forum to disseminate the most rigorous science to scholars and practitioners around the world. Our lofty goals remain the same today as those enumerated by the JEP editorial board 100 years ago - to do no less than make the world a better place for as many as possible as quickly as possible. We invite you to join us in this endeavor!

\section{REFERENCES}

Achilles, C., Finn, J., and Bain, H. (1998). Using class size to reduce the equity gap. Educ. Leadersh. 55, 40-43.

Archambault, I., Janosz, M., Fallu, J., and Pagani, L. (2009). Student engagement and its relationship with early high school dropout. J. Adolesc. 32, 651-670.

Blanchard, M. R., Southerland, S. A., Osborne, J. W., Sampson, V., Annetta, L. A., and Granger, E. M. (2010). Investigating the relative effectiveness of guided inquiry and traditional, didactic laboratory instruction: is inquiry possible in light of accountability? Sci. Educ. 94, 577-616.

Borja, R. (2006). Work skills of graduates seen lacking. Educ. Week 26, 10.

Cleland, J. C. (1990). "Maternal education and child survival: further evidence and explanations," in What We Know About the Health Transition: The Cultural, Social and Behavioural Determinants of Health, Vol. I, eds J. Caldwell, S. Findley, P. Caldwell, G. Santow, J. Braid, and D. Broers-Freeman (Canberra: Health Transition Centre, The Australian National University), 400-419.

Corcoran, T. (1927). The Winnetka school plan. Ir. Mon. $55,63-67$.
Crafts, N. (2000). Globalization and Growth in the Twentieth Century. Washington, DC: International Monetary Fund.

Finn, J., and Achilles, C. (1999). Tennessee's class size study: findings, implications, misconceptions. Educ. Eval. Policy Anal. 21, 97.

Finn, J., Pannozzo, G., and Achilles, C. (2003). The "why's" of class size: student behavior in small classes. Rev. Educ. Res. 73, 321.

Goldberg, A., Russell, M., and Cook, A. (2003). The effect of computers on student writing: a meta-analysis of studies from 1992 to 2002. J. Technol. Learn. Assess. 2, 1-52.

Greene, J., and Winters, M. (2002). High School Graduation Rates in the United States. New York: The Manhattan Institute for Policy Research.

Henderson, M. (2010). Scientists create artificial life in laboratory. The Times. Retrieved May 21, 2010, from http://www.timesonline.co.uk/tol/news/science/biology_evolution/article7132299.ece

Ingersoll, R., and Kralik, J. (2004). The Impact of Mentoring on Teacher Retention: What the Research Says. Denver CO: Education Commission of the States, 1-23.

James, W. (1900). Talks to Teachers on Psychology: And to Students on Some of Life's Ideals. New York: H. Holt.

Lei, J., and Zhao, Y. (2007). Technology uses and student achievement: a longitudinal study. Comput. Educ. 49, 284-296. doi: http://dx.doi.org/10.1016/j. compedu.2005.06.013.

Moyer, P. (2001). Are we having fun yet? How teachers use manipulatives to teach mathematics. Educ. Stud. Math. 47, 175-197.

Osborne, J. W. (2008). Sweating the small stuff in educational psychology: how effect size and power reporting failed to change from 1969 to 1999 , and what that means for the future of changing practices. Educ. Psychol. 28, 1-10.

Papanastasiou, E., Zembylas, M., and Vrasidas, C. (2003). Can computer use hurt science achievement? The USA results from PISA. J. Sci. Educ. Technol. 12, 325-332.

Skinner, B. F. (1960). Teaching machines. Rev. Econ. Stat. 42, 189-191.

Skinner, B. F. (1961). Why we need teaching machines. Harv. Educ. Rev. 31, 377-398.

Slavin, R. (2002). Evidence-based education policies: transforming educational practice and research. Educ. Res. 31, 15.

Thorp, R. (1998). Progress, Poverty and Exclusion: An Economic History of Latin America in the 20th Century. Washington, DC: Inter-American Development Bank.

Wundt, W. (1874). Grundzüge der physiologischen Psychologie. Leipzig: Wilhelm Engelmann.

Received: 06 August 2010; accepted: 03 September 2010; published online: 22 September 2010.

Citation: Osborne JW and Mollette MJ (2010) Grand challenges in educational psychology. Front. Psychology 1:157. doi: 10.3389/fpsyg.2010.00157

This article was submitted to Frontiers in Educational Psychology, a specialty of Frontiers in Psychology.

Copyright ( $(2010$ Osborne and Mollette. This is an openaccess article subject to an exclusive license agreement between the authors and the Frontiers Research Foundation, which permits unrestricted use, distribution, and reproduction in any medium, provided the original authors and source are credited. 